\title{
MORPHOLOGY OF THE RAT CAROTID BODY
}

\author{
Dimitrinka Y. Atanasova ${ }^{1, a}$, Michail E. Iliev ${ }^{2, a}$, and Nikolai E. Lazarov ${ }^{1,3^{*}}$ \\ ${ }^{1}$ Institute of Neurobiology, Bulgarian Academy of Sciences, Sofia, Bulgaria, ${ }^{2}$ Department of Anatomy, \\ Histology and Cytology, Medical University, Pleven, Bulgaria, and ${ }^{3}$ Department of Anatomy and \\ Histology, Medical University, Sofia, Bulgaria
}

The carotid body $(\mathrm{CB})$ is the main peripheral arterial chemoreceptor that registers the levels of $\mathrm{pO}_{2}, \mathrm{pCO}_{2}$ and $\mathrm{pH}$ in the blood and responds to their changes by regulating breathing. It is strategically located in the bifurcation region of each common carotid artery. The organ consists of "glomera" composed of two cell types, glomus and sustentacular cells, interspersed by blood vessels and nerve bundles, and separated by connective tissue. The neuron-like glomus or type I cells contain numerous cytoplasmic organelles and dense-cored vesicles that store and release neurotransmitters. They form both conventional chemical and electrical synapses between each other and are contacted by peripheral nerve endings of petrosal ganglion afferent neurons. The glial-like sustentacular or type II cells sustain physiologic neurogenesis in the adult CB and are thus supposed to be progenitor cells. This new source of adult stem cells may be potentially useful for tissue repair after injury or for cell therapy against neurodegenerative diseases. The CB is a highly vascularized organ and its intraorgan hemodynamics possibly plays a role in the process of chemoreception. There is also evidence that chronic hypoxia induces marked morphological and neurochemical changes within the $C B$ but the detailed molecular mechanisms by which these affect the hypoxic chemosensitivity still remain to be elucidated. Dysregulation of the CB function is implicated in various physiological and pathophysiological conditions, including ventilatory altitude acclimatization and sleep-disordered breathing. Knowledge of the morphological and functional aspects of the CB will contribute to our better understanding of respiratory homeostasis in health and disease. Biomed Rev 2011; 22: 41-55.

Key words: chemoreception, chronic hypoxia, glomus cells, stem cells, structural and neurochemical plasticity, ultrastructure

${ }^{a}$ These authors contributed equally to this article and should be considered first co-authors.

Received 14 December 2011, revised 27 December 2011, accepted 28 December 2011.

Correspondence: Dr Nikolai E. Lazarov, Department of Anatomy and Histology, Faculty of Medicine, Medical University, 1 Sv Georgi Sofiiski Str., BG-1431 Sofia, Bulgaria. Tel.: +359 29172 525, E-mail: nlazarov@medfac.acad.bg 


\section{INTRODUCTION}

The carotid body (CB; also known as the glomus caroticum, carotid corpuscle, carotid ganglion, and carotid gland) is a neural crest-derived paired ovoid mass of tissue, around $2 \mathrm{~mm}$ in diameter in humans and less than $1 \mathrm{~mm}$ in rats. Its small size explains why it was referred to as ganglion minimum in the first anatomical report on its existence in the human body, Hartwing Taube's Doctoral Thesis in 1743, although its discovery is attributed to his mentor, the great German physiologist Albrecht von Haller (1). However, for centuries its function had been completely unknown to scientists. The pioneering studies performed by the Spanish histologist Fernando de Castro $(2$, reviewed in 3,4) and the Flemish physiologist Corneille Heymans, 1938 Nobel Prize Winner in Physiology or Medicine $(5,6)$ constituted the basis for its acceptance as a sensory receptor for chemical changes occurring in the blood. The glomus organ is situated bilaterally at the bifurcation of the common carotid artery (Fig. 1). This location is strategic for monitoring blood chemicals just before they reach the brain, a organ that is critically sensitive to oxygen and glucose deprivation.

The $\mathrm{CB}$ is the main peripheral chemoreceptor that registers the arterial blood levels of $\mathrm{pO}_{2}, \mathrm{pCO}_{2}$ and $\mathrm{pH}$, and responds to their changes by regulating breathing $(7,8)$. It plays an essential role in initiating an appropriate respiratory and cardiovascular response to hypoxia, hypercapnia and acidosis. It has also recently been shown that the $\mathrm{CB}$ is a glucose sensor activated by hypoglycemia (reviewed in 9 ).

The $\mathrm{CB}$ works in concert with the opposing afferent nerve endings of the petrosal ganglion (PG) cells and they together form a functional unit, the $\mathrm{CB}$ chemosensory system. In response to hypoxia $\mathrm{CB}$ sensor cells release a variety of neurotransmitters which activate chemoafferent nerve endings of PG neurons. The latter provide the afferent link between the $\mathrm{CB}$ chemoreceptors and respiratory nuclei in the brainstem, thus ensuring the transmission of the chemosensory information from the chemotransductive cells to the central nervous system. The efferent limb of the chemoreceptor reflex arc is formed by solitary axons projecting to the respiratory centers, distributed in a ponto-medullary respiratory network. They control the coordinated contractions of the abdominal, thoracic and laryngeal respiratory muscles and upon hypoxia stimulate breathing (10).

Much of the available evidence suggests that the CB dysfunction and altered oxygen homeostasis are involved in the pathophysiology of several human diseases, some of which are of a high incidence. Thus, a better knowledge of the basic morphology and physiology of the $\mathrm{CB}$ in a rat model will contribute to our understanding of respiratory homeostasis in health and disease.

\section{GENERAL STRUCTURE OF THE CAROTID BODY}

\section{Normal histology}

For decades rats have widely been used to study the morphology and physiology of the $\mathrm{CB}$. The general organization of the $\mathrm{CB}$ parenchyma in islets of cells was originally described by Kohn (11). The organ is structurally complex and composed of four principal components: cell clusters, blood vessels, connective tissue and nerve fibers $(12,13)$ (Fig. 2A). The small clusters, also known as glomeruli or glomoids, are the basic morphofunctional units of the CB. As originally described (14), they are formed by two juxtaposed cell types: type I or glomus cells (2-12 in each glomerulus in rats, an average of four cells), incompletely invested by 1-3 type II or sustentacular cells (Fig. 2B; see also 5A). Both parenchymal cell types can be clearly distinguished from each other, even at the light microscope level. The principal cell type, the neuron-like glomus cell, is considered the chemosensory cell of the organ and contains secretory granules packed with putative neurotransmitters. Glomus cells, like sympathetic neurons and chromaffin cells of the adrenal medulla, originate from the neural crest (15); therefore the $\mathrm{CB}$ was initially regarded a paraganglion (16). By stereological methods, Laidler and Kay (17) determined that the $\mathrm{CB}$ of the adult rat contains $11,500 \pm 2500$ glomus cells (mean $\pm \mathrm{SE}$ ). Chemoreceptor cells are round to oval in shape and their size usually varies between 8 and $16 \mu \mathrm{m}$. They have a clear, round nucleus and a copious and distinctly granular cytoplasm. Type II cells ( $\sim 15-20 \%$ of all cells) are typically located at the periphery of the cell cluster. They are glial-like cells possessing long-shaped bodies with elongated hyperchromic nuclei, a thin cytoplasmic layer and extended processes that envelop groups of glomus cells. Classically, type II cells were considered to be supporting cells within the organ which play a role in the metabolic support but recently they have been assumed to be the CB stem cells (18-20). The CB also contains some autonomic microganglion cells, embedded within or located at the periphery of the $\mathrm{CB}(2,21,22)$. In rats, the number of these neurons varies from 10 to 20 (21). They mainly provide innervation for the blood vessels but may also have an efferent regulatory action on glomus cells $(21,23)$.

The cell clusters are separated from each other by septa of connective tissue, which converge on the surface to form a capsule for the whole organ (Fig. 3A). Generally, there is rela- 

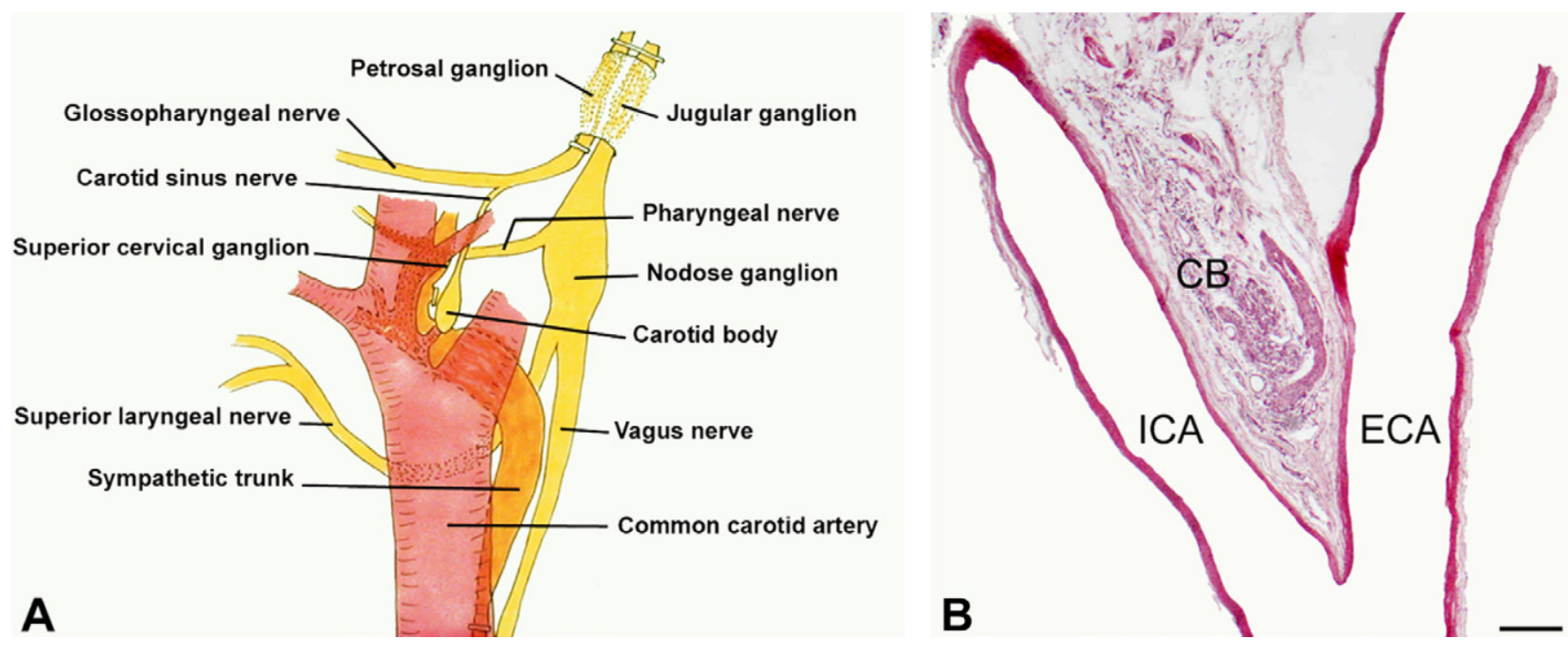

Figure 1. Location of the carotid body (CB) of a rat. (A) Schematic diagram of the bifurcation area of the left common carotid artery. The glomus organ is positioned between the external carotid artery (ECA) and the internal carotid artery (ICA). (B) A lowmagnification $H \& E$ stained section showing the strategic location of the CB between the ECA and ICA. Scale bar $=500 \mu m(B)$.
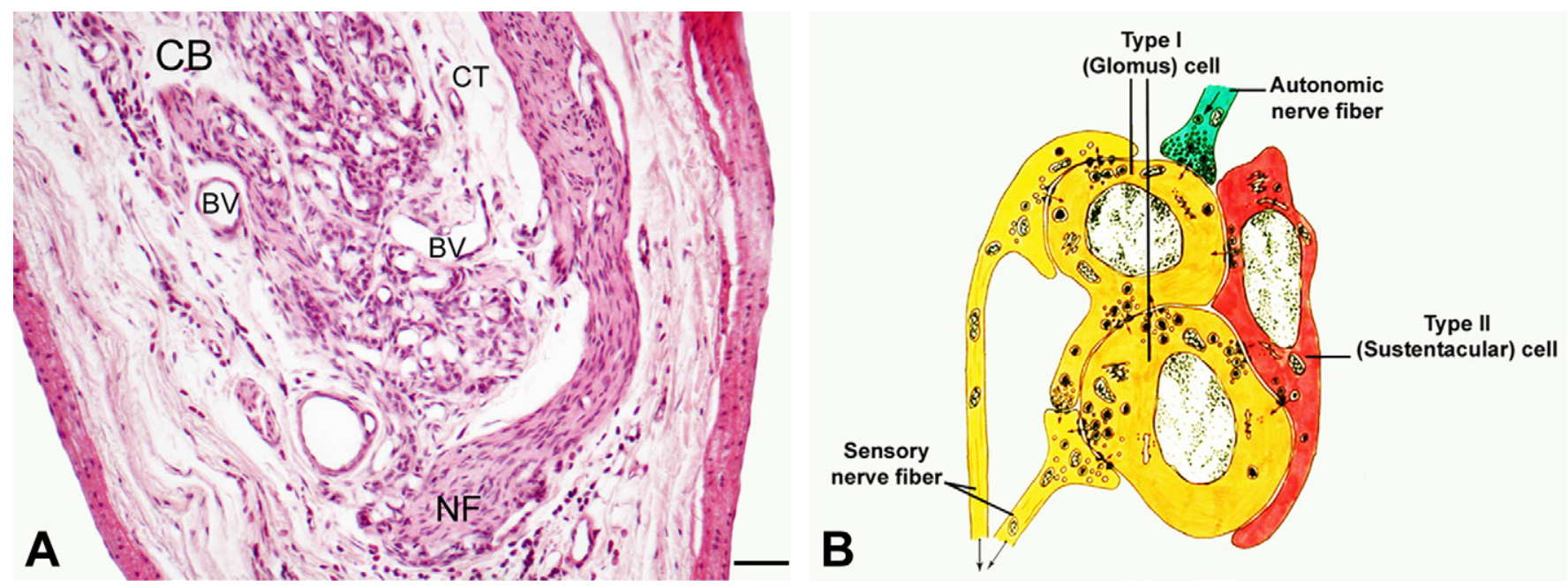

Figure 2. The general structure of the carotid body (CB). (A) $H \& E$ staining illustrates the structural organization of the rat $C B$. The glomic tissue is arranged in cell clusters, glumeruli. Note that a large number of blood vessels (BV) are seen in the $C B$ parenchyma, and some nerve fibers (NF) can also be observed in the surrounding connective tissue (CT). (B) Schematic representation of a CB glomerulus showing the type I (glomus) and type II (sustentacular) cells. Note that neuron-like type I cells are partially enveloped by glial-like type II cells. The glomus cells are dually innervated by both sensory and autonomic nerve fibers. Scale bar $=100 \mu \mathrm{m}(\boldsymbol{A})$. 

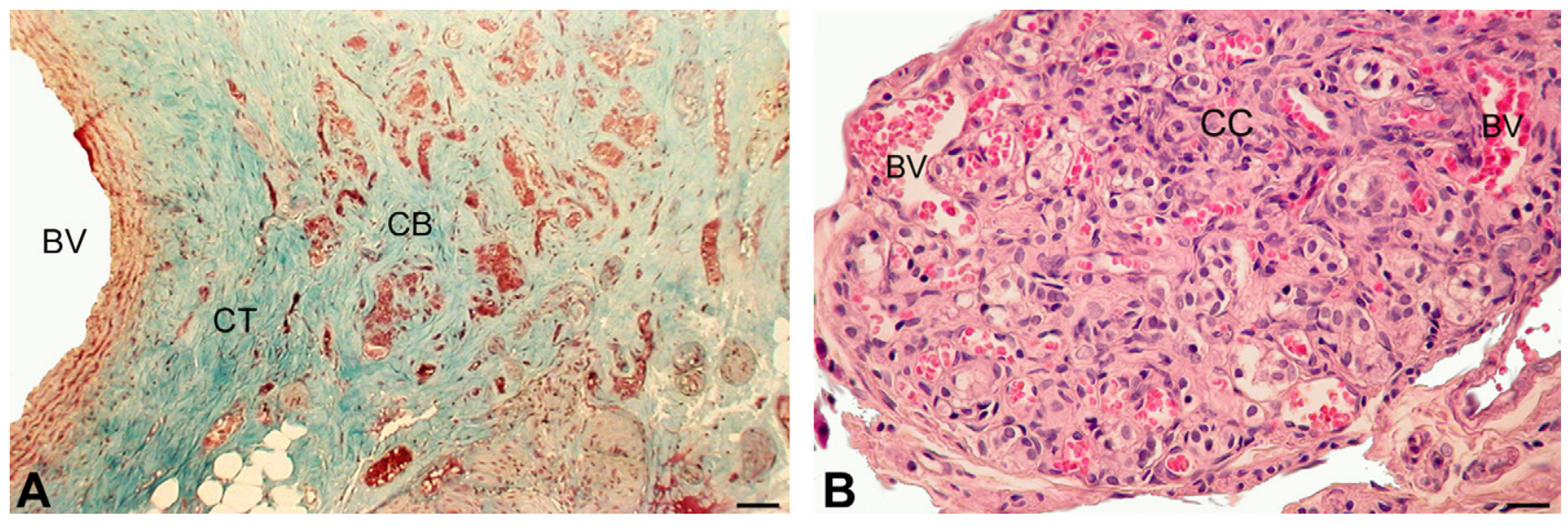

Figure 3. (A) Low-power photomicrograph of a representative Azan-stained rat CB section showing the septa of collagen fibers with vascular connective tissue (CT) which surround tightly packed glomeruli and build up the glomic capsule. (B) A dense network of blood vessels $(B V)$ is also dispersed in the CT. Note the intimate contact of capillaries with the cell clusters (CC). Scale bars $=200 \mu \mathrm{m}(\boldsymbol{A})$ and $50 \mu \mathrm{m}(\boldsymbol{B})$.

tively little connective tissue in the $\mathrm{CB}$ of most young animals and its amount increases with age constituting $50-60 \%$ of the total volume of the adult $\mathrm{CB}$. The stroma around the lobules contains relatively large blood vessels and nerve bundles.

In fact, the most striking anatomical characteristics of the $\mathrm{CB}$ are its rich vascularization and dense innervation. The $\mathrm{CB}$ is one of the most irrigated organs in the body and receives blood supply through a short branch, called the glomic artery, arising from the external carotid artery (13). A profuse capillary network travels in the walls of the connective tissue surrounding the $\mathrm{CB}$ glomeruli (Fig. 3B) and giving a pink-colored appearance to the $\mathrm{CB}$. The capillaries emerge from the $\mathrm{CB}$, anastomose with venules of variable diameters that form a dense venous plexus on the surface of the organ. The venous drainage of the $\mathrm{CB}$ is via one or two small veins, emerging from this superficial plexus, which empty into the internal jugular vein or one of its branches (7).

Since the pioneering work of Fernando de Castro (2) it has been known that the glomus cells are dually innervated by both sensory nerve fibers and autonomic fibers via the ganglioglomerular nerves (Fig. 4). The sensory nerve fibers which convey chemosensory impulses from the carotid body into the brainstem are mainly supplied by the carotid sinus nerve (also known as Hering's nerve) and their cell bodies are located in the PG of the glossopharyngeal nerve (24). In rats, there are about 450-750 axons in the carotid sinus nerve and the majority of them are unmyelinated fibers (22). Entering the cell cluster, each of these branches so as to innervate more than 20 glomus cells (Fig. 4A). In addition, the carotid body in the rat receives sensory innervation from the superior (jugular) ganglion and inferior (nodose) ganglion of the vagus nerve $(24,25)$. As can be obtained from Fig. 4 , the sympathetic nerve supply is provided by postganglionic neurons from the closely located superior cervical ganglion (SCG) $(26,27)$. Most sympathetic nerve fibers are thought to supply blood vessels and a few of them may also innervate glomus cells (13). Parasympathetic neurons scattered around the carotid body have been described as the (internal) carotid ganglion (28).

\section{ELECTRON MICROSCOPY OF THE NORMAL RAT CAROTID BODY}

\section{Ultrastructure of the parenchymal cells}

Ultrastructural studies have shown that glomus cells have the morphological characteristics of actively synthesizing cells (12). Indeed, as seen with the transmission electron microscope, their cell bodies contain a large round, euchromatic nucleus and an abundant pale cytoplasm with numerous organelles (Fig. 5B). Amongst them, most notable are the multiple free ribosomes and polysomes, the flattened cisternae of rough endoplasmic reticulum, the well-developed Golgi apparatus and a large number of compact mitochondria. Another remarkable ultrastructural feature of these cells is the presence of osmiophilic dense-cored vesicles in their cytoplasm, where they are not randomly distributed. Indeed, they are rare in the Golgi region and occur in large groups tending to accumulate in the periphery of the cells (Fig. 5C). The size of the dense- 

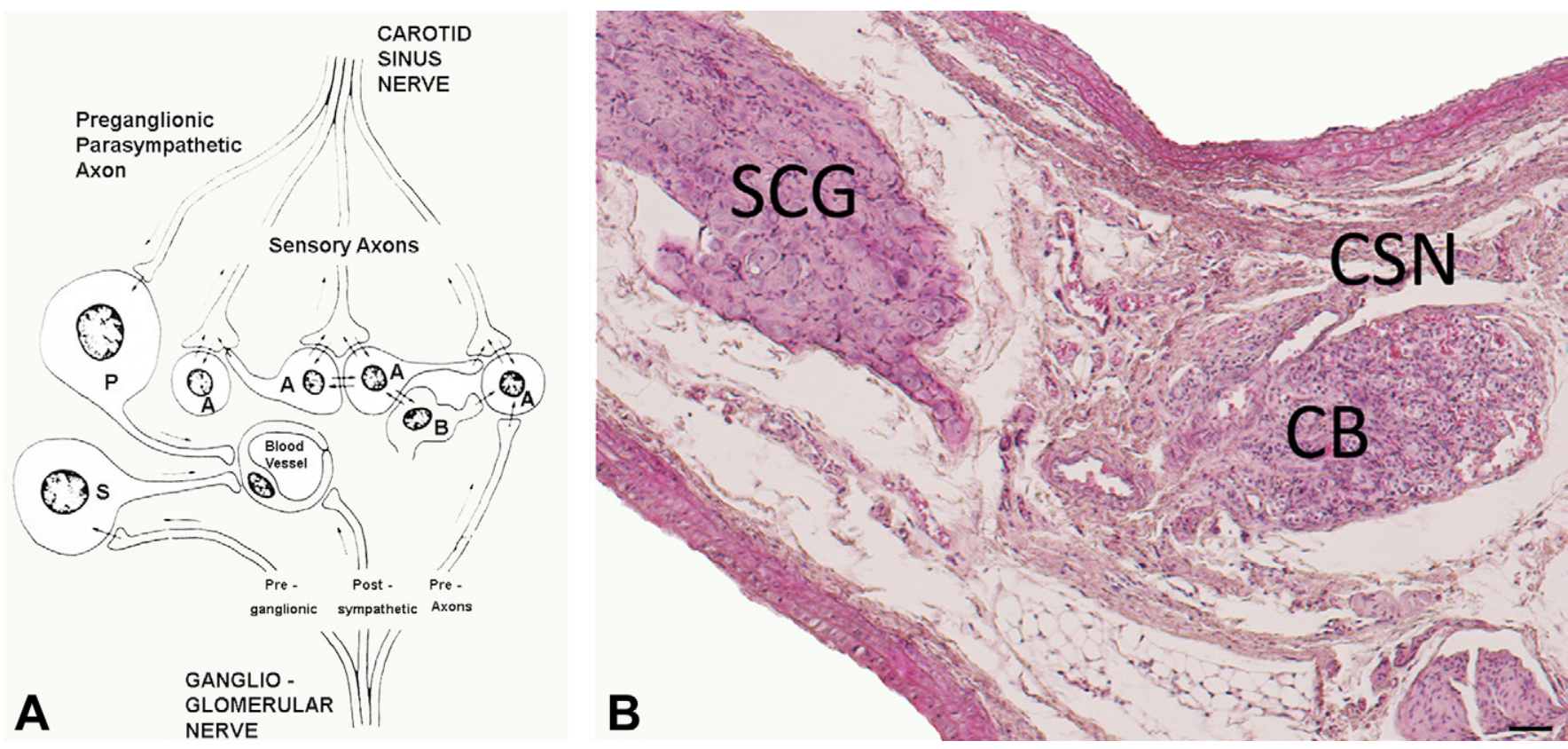

Figure 4. (A) Schematic drawing of the rat carotid body (CB) innervation. The sensory nerve supply of the chemosensory glomus cells is provided by $P G$ neurons through the carotid sinus nerve (CSN). The sympathetic innervation is performed by postganglionic neurons from the closely located superior cervical ganglion (SCG) via the ganglioglomerular nerve. They mostly supply the blood vessels although some of them may also innervate the CB parenchyma. (B) Histological picture of the rat CB indicating its innervation from the adjacent SCG. CSN, carotid sinus nerve. Scale bar $=150 \mu \mathrm{m}(\boldsymbol{B})$.

cored vesicles in the rat ranges from 50-200 $\mathrm{nm}$ (mean diameter about $100 \mathrm{~nm})(21,29)$. Although smaller in size, they closely resemble the granules of paraneurons belonging to the diffuse neuroendocrine system cell family. In particular, the cytological features of the glomus cells are quite similar to the adrenal chromaffin cells and ganglionic small intensely fluorescent (SIF) cells. Similar to them, the glomus cells contain various biogenic amines and neuropeptides in the dense-cored granules $(7,8,25,30)$. This similarity, together with findings from developmental studies as already noted, has lead historically to the concept of classical "Paraganglion" (18) and recently to that of "Paraneuron" (31). Therefore, all this is in favor of the proposal that the carotid body can be regarded as a secretory organ.

On the basis of the size and staining properties of their dense-cored vesicles, McDonald and Mitchell (21), and independently Hellström (32) categorized two subtypes of glomus cells: type A or large vesicle cells (mean vesicle diameter 116 $\mathrm{nm}$ ) and type B or small vesicle cells (mean vesicle diameter $90 \mathrm{~nm}$ ). The authors estimated that in rats type A cells comprise $51 \pm 10 \%$ (mean \pm S.D.) of the glomus cells. Besides, the population density of these granules varies between glomus cells, and this may be indicative of differing states of secretory activity within the CB. Smaller in number and size (about 40 $\mathrm{nm}$ in diameter) clear vesicles also occur in rat glomus cells (29). They tend to accumulate in the cell processes and occasionally in the regions facing the nerve endings.

The sustentacular cells contain a paucity of organelles in their cell bodies. The most distinguishing feature of these cells is the absence of secretory granules in their cytoplasm suggesting that they do not synthesize and store neurotransmitters. Therefore, despite their location in close proximity to the blood in the capillaries, they do not play a role in chemosensory function. Nonetheless, Golgi apparatus, ribosomes, scattered endoplasmic reticulum and occasional mitochondria are present, though developed to a lesser extent than in glomus cells (Fig. 5D). They also contain abundant, intermediate vimentin filaments and possess glial-like traits necessary to support and influence the behavior of glomus cells (33). Indeed, type II cells express glial markers such as the S-100 protein and glial fibrillary acidic protein $(18,34)$. Another distinguishing feature of these cells is their possession of long cytoplasmic processes that extend away, partially envelop chemoreceptor cells and collectively form a protective network around them. 

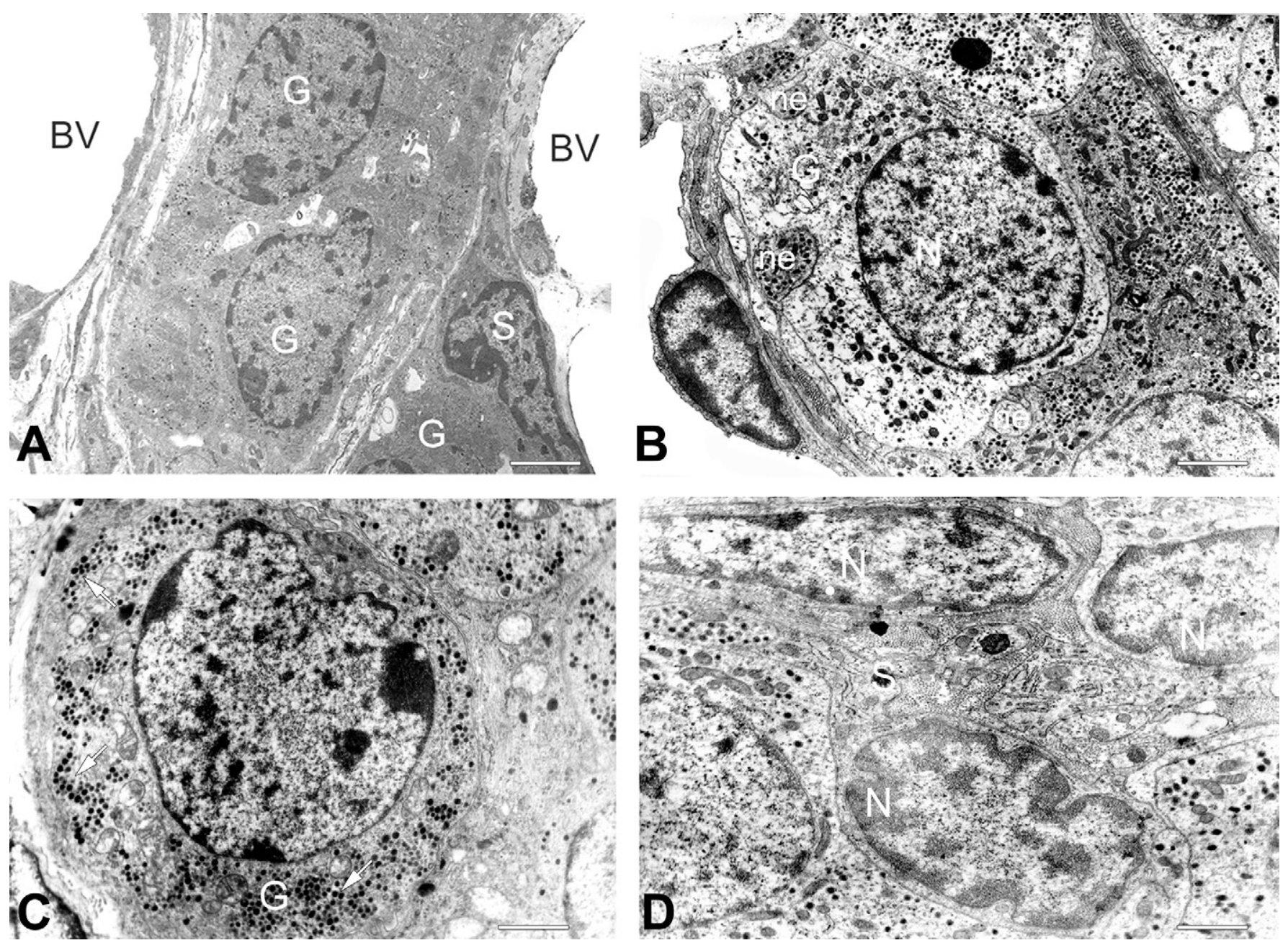

Figure 5. Ultrastructure of the CB parenchyma. (A) An ultrathin section of a rat CB glomerulus indicating at a lower magnification a typical tightly packed cell cluster of glomus cells $(G)$ adjacent to blood vessels (BV). Two glomus cells are partially invested by a sustentacular cell (S). (B) Electron micrograph of a glomus cell $(G)$ with a round, euchromatic nucleus $(N)$ and an abundant cytoplasm with numerous dense-cored vesicles. Note that some nerve endings (ne) are visible in the vicinity of the glomus cell. (C) shows the accumulation of dense-cored vesicles (arrows) in the periphery of a glomus cell (G). (D) Electron micrograph of a section through the peripheral region of a glomerulus. The sustentacular cells (S) possess elongated hyperchromatic nuclei (N) with a vesicle-free cytoplasm and long processes. Scale bars $=0.5 \mu \mathrm{m}(\boldsymbol{A})$ and $1 \mu \mathrm{m}(\boldsymbol{B}-\boldsymbol{D})$.

Like Schwann cells, they may completely ensheath single or small groups of unmyelinated nerve fibres in the $\mathrm{CB}$, thus guiding the axons to the glomus cells in the space between the Schwann cells and cell clusters.

\section{Synaptic organization}

The synaptic connections of the organ have been characterized in the greatest details in the rat $\mathrm{CB}$. The advent of the conventional electron microscopy has indicated that many adjacent glomus cells make "synaptic"-like somato-somatic contacts (Fig. 6A), thus explaining the characteristic morphological picture of cell clustering in the $\mathrm{CB}(7,12,13)$. The intercellular space between the contacting cells is about 20 $\mathrm{nm}$. Notably, both large dense-cored vesicles and small clear vesicles accumulate at this synaptic junction. Recent studies by freeze-fracture electron microscopy (35) have additionally revealed the existence of gap junctions between some glomus cells in the CB which have been designated as electrical syn- 

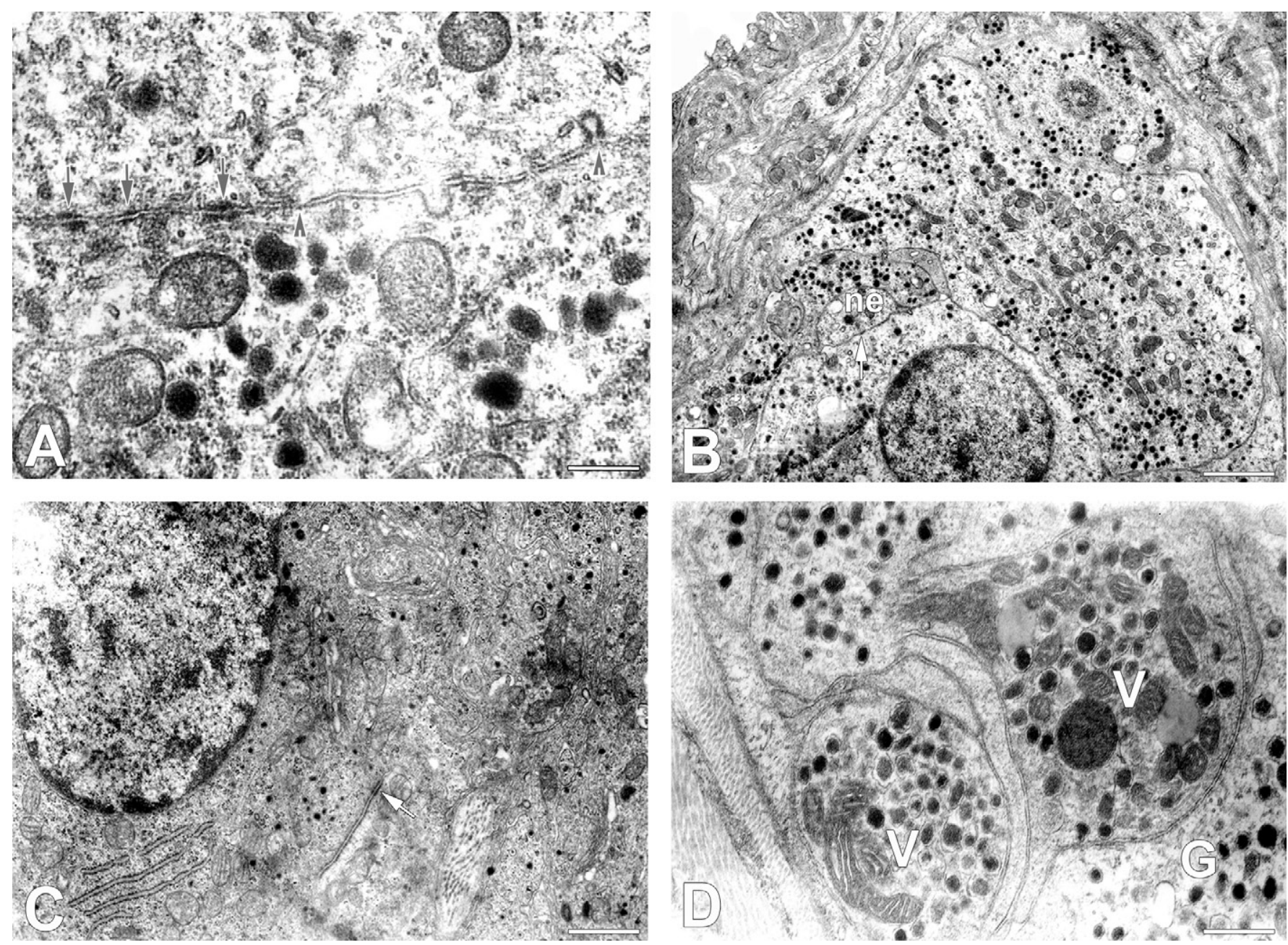

Figure 6. Synaptic organization of the rat carotid body (CB). (A) Detail of the cell junction between two glomus cells illustrating zones of close membrane appositions representing gap junctions (arrowheads) and the synaptic-like synaptic contacts (arrows). Note the numerous small clear vesicles and a few large dense-cored vesicles at the periphery of the contacting cells. (B) Electron micrograph showing a sensory nerve ending (ne) making a synaptic contact (arrow) with a glomus cell. (C) A spherical clear vesicle-containing axon terminal forming a symmetrical synaptic contact (arrow) with a glomus cell body. (D) An autonomic nerve fiber with characteristic varicosities (V) containing numerous dense-cored vesicles and mitochondria in the vicinity of a glomus cell (G). Scale bars $=0.15 \mu \mathrm{m}(\boldsymbol{A})$ and $1 \mu \mathrm{m}(\boldsymbol{B}-\boldsymbol{D})$.

apses (Fig. 6A). Interestingly, gap junctions may also occur between glomus and sustentacular cells and such junctional specializations are observed between glomus cells and afferent nerve endings as well (36). The electrotonic coupling allows intercellular exchange of ions and small molecules and the passage of currents (37). Moreover, cell uncoupling increases the transmitter release, whereas tighter coupling reduces it (38). Besides, it has been found that the glomus cells are contacted by peripheral nerve endings of $\mathrm{PG}$ afferent neurons
(Fig. 6B) (see 12,13). Sensory nerve endings on glomus cells may also appear as boutons "en passant", making multiple synaptic contacts (39). The presynaptic terminal contains a large number of mitochondria, numerous small (about $60 \mathrm{~nm}$ in diameter in the rat), clear vesicles (Fig. 6C) and a few large (usually 70-150 nm in diameter) dense-cored vesicles. Some larger boutons apposed to chemoreceptor cells and typically seen as axonal varicosities are filled with abundant densely packed small clear vesicles, large dense-cored vesicles and 
mitochondria (Fig. 6D). They are considered preganglionic sympathetic efferent nerve endings, thus favoring the concept of the dual sensory and motor innervation of the $\mathrm{CB}(21,40,41)$. Such synaptic connections have also been shown on some ganglionic SIF cells (42). Sometimes (i.e. in about $10 \%$ of the cases), the "afferent" and "efferent" synapses are adjacent to each other forming reciprocal synapses in the $\mathrm{CB}(7,12)$. The synaptic contacts on glomus cells are with both symmetric and asymmetric membrane morphology and have functionally been described as bidirectional (12). It is likely that in response to natural stimuli peripheral processes of PG neurons release chemical substances at synapses triggering the exocytosis of one (or more) neurotransmitter(s) from the glomus cells (43). The released transmitter, acting on specific postsynaptic receptors, increases the rate of chemosensory discharge in nerve fibers of PG neurons projecting to the $\mathrm{CB}(7,44)$.

In addition to nerve-glomus cell contacts, nerve endings are occasionally observed to make synaptic contact with another nerve or nerve ending (Fig. 7A, B). The presynaptic profile possesses a few mitochondria, and always contains groups of
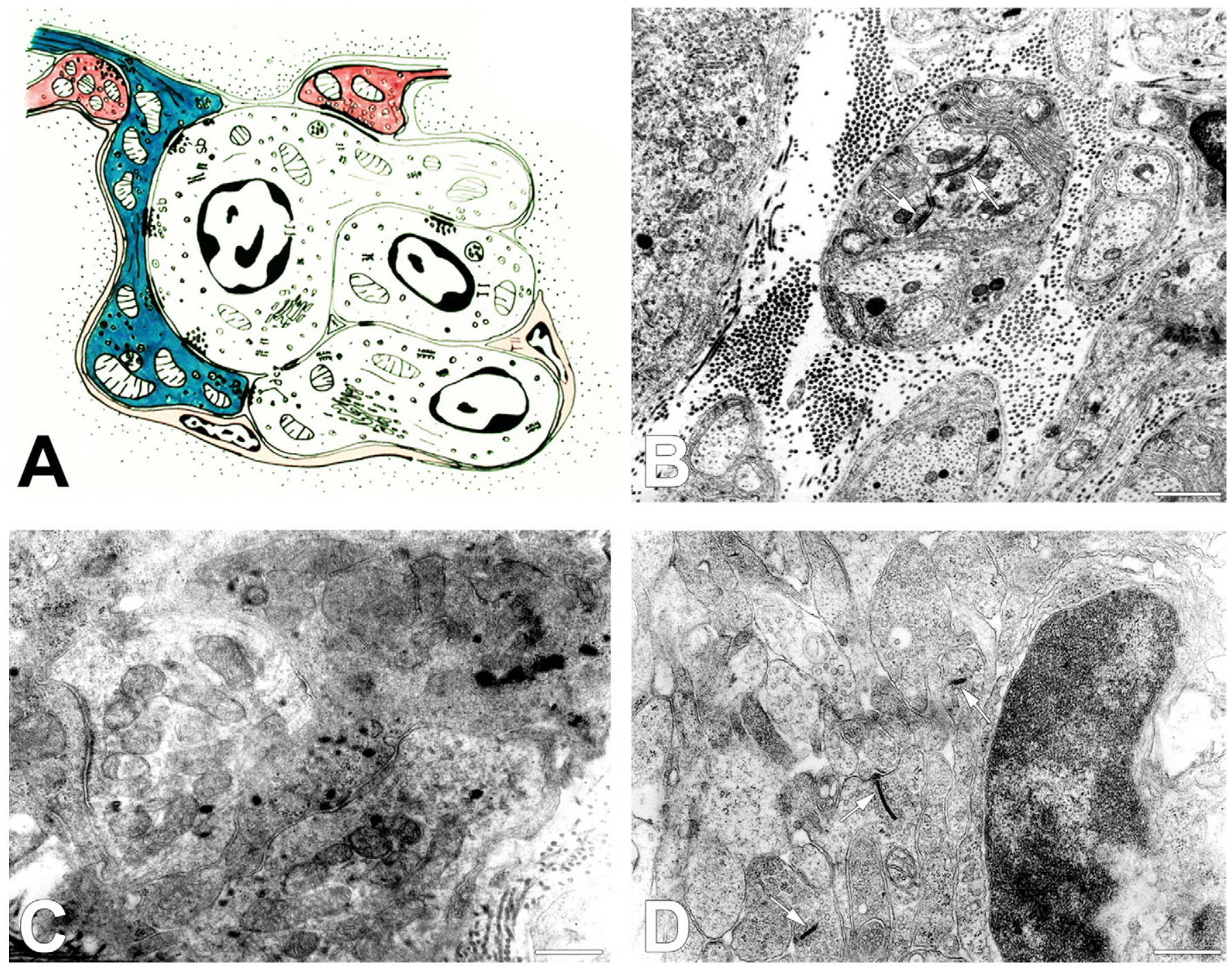

Figure 7. Nerve-nerve ending relationships in the rat CB. (A) Schematic drawing of axo-axonic synaptic contacts with a symmetrical appearance. (B) Electron micrograph showing typical axo-axonic synapses in the rat $C B$. (C) The presynaptic profile contains a few mitochondria and groups of both small clear and occasional large dense-cored vesicles. (D) Ribbon synapses with the characteristic arrangement of electron dense structures (arrows) called synaptic body or ribbon in the presynaptic bouton apposing the postsynaptic terminal. Scale bars $=0.5 \mu \mathrm{m}(\boldsymbol{B}-\boldsymbol{D})$. 
clear vesicles as well as occasional dense-cored vesicles (Fig. 7C). The same structures, i.e. mitochondria, clear vesicles and a few dense-cored vesicles are present also in the postsynaptic nerve ending. Usually these axo-axonic synaptic contacts have a symmetrical appearance. Interestingly, a presynaptic dense body is sometimes seen denoting this synaptic contact as a ribbon synapse (Fig. 7D). This type of synapse typically links some particular sensory receptor cells. The ribbon has been proposed to shuttle synaptic vesicles to exocytotic sites, promote their release at the synapse and thus enable a rapid information processing.
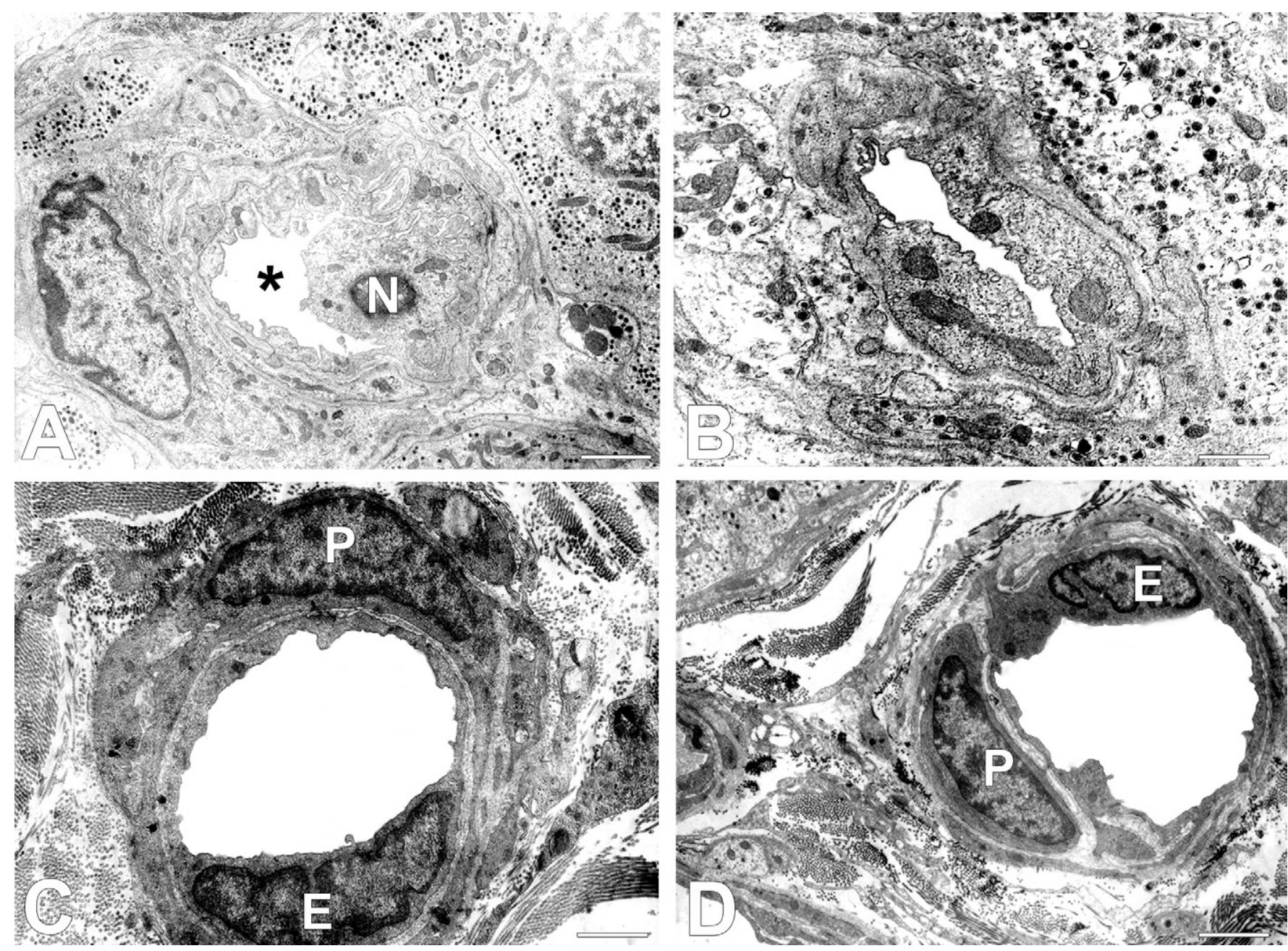

\section{Microvasculature ultrastructure}

Most blood vessels in the CB are capillaries, which are abundant and closely packed. According to their morphological features and size, two types of capillaries have been identified in the CB (45-47). Type I capillaries are the prevailing type (60\% of the total). They are convoluted, larger in size (8-20 $\mu \mathrm{m}$ in diameter) and have a thin wall, formed by a fenestrated endothelium with short microvilli, a basal lamina $(50-100 \mathrm{~nm}$ in thickness) beneath and an incomplete covering of pericytes (Fig. 8A). Endothelial cytoplasm contains scant mitochondria, numerous micropinocytotic vesicles and occasional

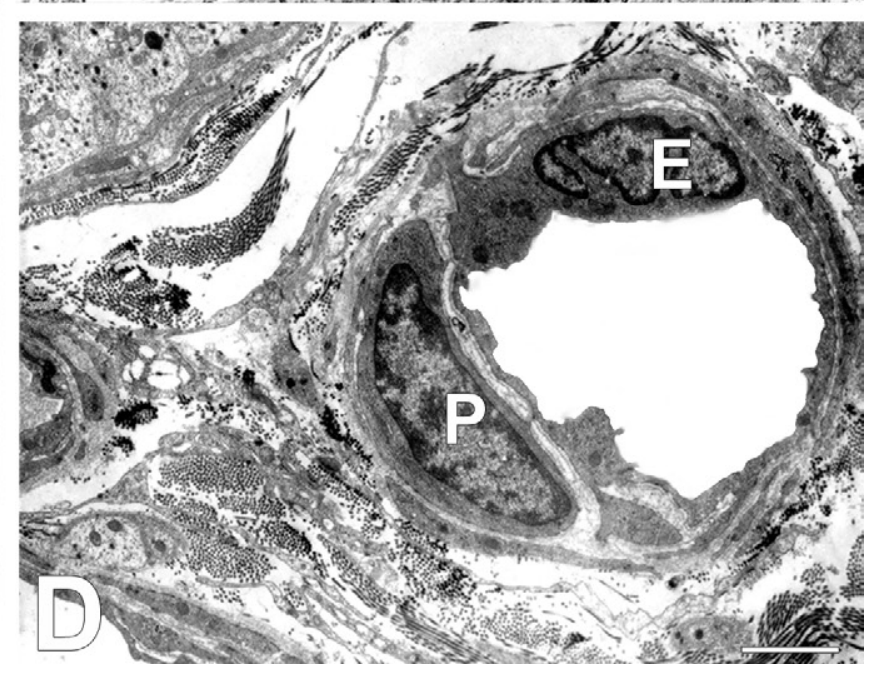

Figure 8. Ultrastructure of capillaries in the rat CB. (A) A type I capillary (asterisk) closely associated with the cell clusters. Its thin wall is formed by a fenestrated endothelium containing the nucleus $(N)$ and an attenuated part with short microvilli, lies on a basal lamina and is partially covered by a pericyte. (B) The endothelial cytoplasm of a fenestrated capillary with scant mitochondria and numerous micropinocytotic vesicles. $(\boldsymbol{C}, \boldsymbol{D})$ Cross section profiles of continuous type II capillaries showing the thick portion of the endothelial cytoplasm $(E)$ and pericytes $(P)$ investing them. Note the 'perisinusoidal' space filled with collagen fibers. Scale bars $=1 \mu \mathrm{m}$. 
Weibel-Palade bodies (Fig. 8B). These capillaries are closely associated with the cell clusters. Despite their morphological features, the fenestrated capillaries of the $\mathrm{CB}$ are not true sinusoids. They rather resemble the fenestrated capillaries of the adrenal medulla and other endocrine glands, mediating the characteristic hyperpermeability state in the CB. Type II capillaries are mostly straight, typically thinner (6-12 $\mu \mathrm{m}$ in diameter) and continuous. They are covered by pericytes and do not make contacts with cell clusters (Fig. 8C, D). The glomus cells are separated from the capillary endothelium by a 'perisinusoidal' space containing collagen and are lined on both sides by a basement membrane applied to the contiguous walls of glomus and endothelial cells (39). Collagen fibres are present not only in the "perisinusoidal" space but are also found to a variable extent between the glomus cells. Bundles of myelinated and unmyelinated axons are frequently seen in "perisinusoidal" and intercellular spaces.

\section{MORPHOLOGICAL CHANGES IN THE HYPOXIC CAROTID BODY}

Chronic hypoxia induces gene expression, leading to profound morphological changes in the CB. Hollinshead (48) was the first to describe cytological modifications of CB cells after a severe and sustained hypoxia, and similar investigations were also done with the electron microscope as early as 1958 by Hoffman and Birrel (49). Generally, the long term hypoxic exposure enlarges several-fold the size of the rat $\mathrm{CB}(50,51)$ causing glomus cell hypertrophy and hyperplasia (52-54). In addition, there is a decrease in the covering of glomus cells by sustentacular cells (55) and this alteration increases the potential area available for gap junction connections between the glomus cells, which have been shown to enhance glomus cell sensitivity (56). Although no structural changes in the sustentacular cells have been observed under such conditions, there is evidence that hypoxic adaptation of the rat $\mathrm{CB}$ involves proliferation of these cells as well $(53,54)$. Also, systemic hypoxia changes the $\mathrm{CB}$ vascular structure, inducing marked (10-fold in rats) vasodilation (51) and the growth of new blood vessels $(54,57)$. In fact, the number of blood vessels remains unchanged but a vascular remodeling and proliferation of endothelial cells of existing blood vessels occur during chronic hypoxia (58).

In humans such a physiological adaptive response to prolonged hypoxia occurs during acclimatization to high altitudes $(54,59)$ or pathologically in patients suffering from systemic hypertension and/or cardiopulmonary diseases with concomi- tant hypoxemia (reviewed in 60).

\section{NEUROCHEMICAL PLASTICITY OF THE CAROTID BODY IN CHRONIC HYPOXIA}

In addition to the remarkable structural plasticity, chronic hypoxia induces changes in the neurotransmitter profile of chemosensory cells in the CB. It is well established that hypoxia causes glomus cells to depolarize and release (both excitatory and inhibitory) transmitters, which bind to autoreceptors expressed by type I cells or postsynaptic receptors on apposed chemoafferent nerve terminals (7). Multiple putative neurotransmitters are thought to mediate signals generated by hypoxia. The predominant excitatory transmitter synthesized and released by type I cells in response to hypoxia is still a matter of debate (7). Current evidence suggests that acetylcholine (ACh) and adenosine triphosphate (ATP) are two major excitatory neurotransmitter candidates in the rat hypoxic $\mathrm{CB}$ (for recent reviews, see 8,43). Based on observations accumulated during the first half of the $20^{\text {th }}$ century, the so-called cholinergic and purinergic hypotheses for hypoxic chemosensitivity were introduced (see 61). Moreover, the co-release of ACh and ATP has been proposed to be the main mechanism mediating hypoxic chemotransmission in the rat $\mathrm{CB}(62,63)$, which constitutes the so-called cholinergic-purinergic hypothesis (61). Conversely, it has been reported that despite biochemical evidence for its excitatory action in the CB $(7,43)$, pharmacological and physiological studies indicate that dopamine (DA), which is secreted by the glomus cells, has a primarily inhibitory role in rat $\mathrm{CB}$ chemoexcitation $(8,54)$, the dopaminergic hypothesis (61). Other neurotransmitters present in the $\mathrm{CB}$ and postulated to be important in chemoreception, namely norepinephrine and serotonin, have not been shown to play an important role in hypoxic acclimatization of the $\mathrm{CB}$ to date (reviewed in 64). Our recent studies have proved the modulatory role of histamine as a transmitter in hypoxic chemosensitivity in rats $(65,66)$. On the other hand, chronic hypoxia increases the inhibitory effect of nitric oxide (NO) and reactive oxygen species on glomus cells of rat CB (67). Based on these studies, it has been proposed that hypoxia augments the $\mathrm{CB}$ activity by inhibiting the NO-synthesizing enzyme, nitric oxide synthase (68). Altered peptidergic innervation of the rat $\mathrm{CB}$ also occurs during the course of hypoxic adaptation (69).

\section{CAROTID BODY AND MECHANISMS OF DISEASE}

Peripheral chemoreceptors have been implicated in various dis- 
eases, including sleep-disordered breathing, congestive heart failure, and certain forms of hypertension (reviewed in 70). In the healthy fetus, the $\mathrm{CB}$ does not significantly contribute to fetal breathing, or in its activity necessary for establishing rhythmic breathing at birth (71). However during the early postnatal life, human infants seem to be particularly vulnerable to hypoxic and hypercapnic episodes during sleep and to changes in peripheral chemoreceptors resulting in altered chemosensitivity which may be one of the factors contributing to a higher incidence of sudden infant death syndrome (SIDS), a disease responsible for unexpected deaths in newborns (72). Indeed, smaller than usual in size CBs or abnormalities in their transmitter content have been reported in victims of the SIDS (73-75). Similarly, a tiny CB with a marked decrease in the number of glomus cells and their dense-cored vesicles has been seen in subjects with congenital central hypoventilation syndrome (76). On the other hand, abnormal enlargement of the $\mathrm{CB}$ and hypersensitivity to hypoxia has been shown in spontaneously hypertensive rats and in humans with essential hypertension but not with renal hypertension (77). Biochemical studies have additionally showed elevated catecholamines in the $\mathrm{CB}$ in essential hypertension (77). Available data suggest enhanced chemoreceptor reflexes in early stages of recurrent apneas, congestive heart failure, and certain forms of hypertension (see 70). Finally, CB denervation plays a critical role in the increased sympathetic activity found in patients with obstructive sleep apnea syndrome, an obesity-related disorder that can cause serious cardiovascular and neurocognitive problems $(78,79)$. It is likely that the CB tends to maintain oxygen homeostasis by marked morphological and neurochemical changes and, thus, acts as a defense mechanism to prevent the progression of morbidity associated with these diseases.

\section{APPLICATION OF CAROTID BODY STEM CELLS TO CELL THERAPY}

Intriguingly, recent experimental data suggest that the mammalian CB is a neurogenic center and its stem cells could be potentially useful for cell therapy in Parkinson's disease (18). In fact, research in Dr López-Barneo's laboratory revealed that the adult type II cells are dormant stem cells that in response to physiologic hypoxia can proliferate and differentiate into new glomus cells (18-20). Detailed knowledge about the CB stem cells responsible for the neurogenic activity in the organ is needed since cells derived in vitro from progenitors exhibit the characteristic complex functional properties of mature glomus cells (18). Because of their dopaminergic nature, glomus cells have been used for intrastriatal CB transplantation studies in Parkinson's disease (80-83). Additional potential advantages of the $\mathrm{CB}$ tissue for cell therapy rely on its survival in hypoxic environments, similar to those existing in the brain parenchyma after a tissue graft (20). Intracerebral administration of CB cell aggregates or dispersed cells has also been tested for the treatment of an experimental model of stroke as the CB autotransplantation significantly reduces stroke-induced behavioral deficits and cerebral infarction (84). Therefore, expansion and differentiation of $\mathrm{CB}$ progenitors in vitro which can differentiate into functionally normal glomus cells may be a useful procedure for the production of a cell mass, thus permitting the successful development of neurological cell replacement therapy. Understanding the cellular interactions in the CB stem cell microenvironment (cell niche) and the molecular events responsible for the maintenance of multipotency of $\mathrm{CB}$ stem cells might settle the issue of small number of CB cells (see Fig. 9).

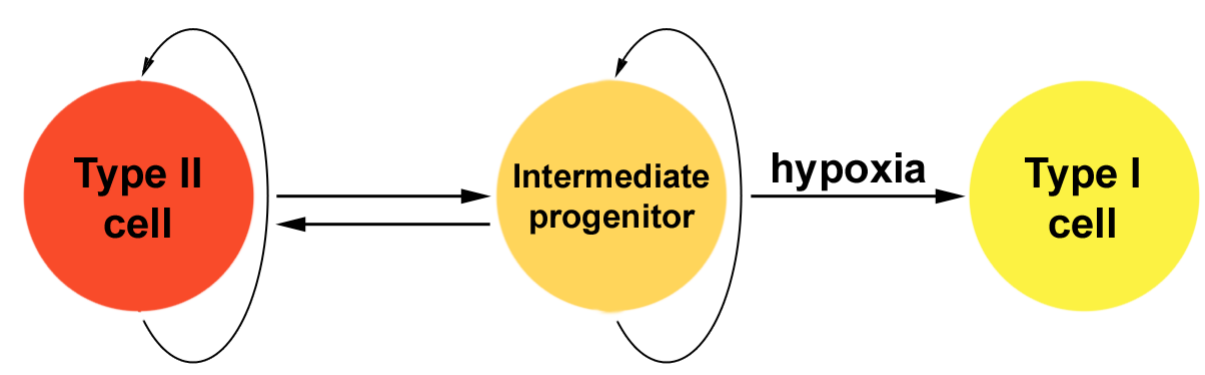

Figure 9. Schematic drawing of cellular events taking place in the carotid body (CB) stem cell niche during a hypoxia/renormoxia cycle. The type II cells are quiescent (or slowly dividing) CB stem cells that can be reversibly converted into intermediate progenitors, which in turn, upon exposure to hypoxia, give rise to mature type I cells. Modified from Pardal et al, 2007 (based on ref. 18). 


\section{CONCLUSION}

Looking back on a large number of previous studies, the morphological and functional organization of the rat $\mathrm{CB}$ has been consistently demonstrated. Based on them, it has been widely believed that hypoxia is transduced by glomus cells organized in cell clusters where they make both reciprocal chemical and electrical synapses with each other. Glomus cells receive sensory innervation from PG chemoafferents and are intimately associated with sustentacular cells and the blood supply. Recent advances in CB research and in understanding morphological and physiological mechanisms that operate in it have revealed that chemoreception involves the interaction between glomus cells, between glomus and sustentacular cells, and, most importantly, between glomus cells and chemosensory nerve terminals. Such arrangement is ideally suited for both the autocrine and paracrine regulation of the glomus cell function (8). It can be inferred that the CB has an intricate internal structure and a remarkable ability to release in response to different chemostimuli a broad variety of transmitter agents that provide clues on its important role in the homeostatic maintenance of the whole organism.

\section{ACKNOWLEDGEMENTS}

The authors thank Dr Angel Dandov for critical reading of the manuscript.

\section{REFERENCES}

1. Pick J. The discovery of the carotid body. J Hist Med Allied Sci 1959; 14: 61-73.

2. De Castro F. Sur la structure et l'innervation de la glande intercarotidienne (glomus caroticum) de l'homme et des mammifères, et sur un noveau système d'innervation autonome du nerf glossopharyngien. Trab Lab Invest Biol Univ Madrid 1926; 24: 365-432.

3. De Castro F. The discovery of sensory nature of the carotid bodies-invited article. Adv Exp Med Biol 2009; 648: 1-18.

4. De Castro F. Towards the sensory nature of the carotid body: Hering, De Castro and Heymans. Front Neuroanat 2009; 3: 23.

5. Heymans C, Bouckaert JJ. Sinus caroticus and respiratory reflexes: I. Cerebral blood flow and respiration. Adrenaline apnoea. J Physiol 1930; 69: 254-266.

6. Heymans C, Bouckaert JJ, Dautrebande L. Sinus carotidien et réflexes respiratoires: II. Influences respiratoires réflexes de l'acidose, de l'alcalose, de l'anhydride carbonique, de l'ion hydrogéne et de l'anoxémie: Sinus carotidiens et échanges respiratoires dans le poumons et au dela des poumons. Arch Int Pharmacodyn Ther 1930 ; $39: 400-448$.

7. Gonzalez C, Almaraz L, Obeso A, Rigual R. Carotid body chemoreceptors: from natural stimuli to sensory discharges. Physiol Rev 1994; 74: 829-898.

8. Nurse CA. Neurotransmission and neuromodulation in the chemosensory carotid body. Auton Neurosci 2005; 120: 1-9.

9. Lopez-Barneo J. Oxygen and glucose sensing by carotid body glomus cells. Curr Opin Neurobiol 2003; 13: 493499.

10. Dutschmann M, Paton JF. Inhibitory synaptic mechanisms regulating upper airway patency. Respir Physiol Neurobiol 2002; 131: 57-63.

11. Kohn A. Über den Bau und die Entwicklung der sogen. Carotidsdrüse. Arch F Mikroscop Anat Bd 1900; 56: 81-148.

12. McDonald DM. Peripheral chemoreceptors. Structurefunction relationships of the carotid body. In: Hornbein TF, editor. Regulation of Breathing. Dekker, New York, 1981; 105-319.

13. Verna A. The mammalian carotid body: morphological data. In: Gonzalez C, editor, The carotid body chemoreceptors. Landes Bioscience, Austin, 1997; 1-29.

14. Gomez LP. The anatomy and pathology of the carotid gland. Am J Med Sci 1908; 136: 98-110.

15. Le Douarin N. The neural crest. Cambridge University Press, London, 1982.

16. Kohn A. Die Paraganglien. Arch F Mikroscop Anat Bd 1903; 62: 263-365.

17. Laidler P, Kay JM. The effect of chronic hypoxia on the number and nuclear diameter of type I cells in the carotid bodies of rats. Am J Pathol 1975; 79: 311-318.

18. Pardal R, Ortega-Sáenz P, Durán R, López-Barneo J. Glialike stem cells sustain physiologic neurogenesis in the adult mammalian carotid body. Cell 2007;131 :364-377.

19. Pardal R, Ortega-Sáenz P, Durán R, Platero-Luengo A, López-Barneo J. The carotid body, a neurogenic niche in the adult peripheral nervous system. Arch Ital Biol 2010; 148: 95-105.

20. López-Barneo J, Pardal R, Ortega-Sáenz P, Durán R, Villadiego J, Toledo-Aral JJ. The neurogenic niche in the carotid body and its applicability to antiparkinsonian cell therapy. J Neural Transm 2009;116:975-982.

21. McDonald DM, Mitchell RA. The innervation of glomus cells, ganglion and blood vessels in the rat carotid body: 
a quantitative ultrastructural study. J Neurocytol 1975; 4: 177-230.

22. McDonald DM. Morphology of the rat carotid sinus nerve. I. Course, connections, dimensions and ultrastructure. $J$ Neurocytol $1983 ; 12: 345-372$.

23. Gauda EB, Cooper R, Johnson SM, McLemore GL, Marshall C. Autonomic microganglion cells: a source of acetylcholine in the rat carotid body. J Appl Physiol 2004; 96: 384-391.

24. Hess A, Zapata P. Innervation of the cat carotid body: normal and experimental studies. Fed Proc 1972; 31: 1365-1382.

25. Ichikawa H. Innervation of the carotid body: immunohistochemical, denervation, and retrograde tracing studies. Misrosc Res Tech 2002; 59: 188-195.

26. Kummer W, Gibbins IL, Stefan P, Kapoor V. Catecholamines and catecholamine-synthesizing enzymes in guinea pig sensory ganglia. Cell Tissue Res 1990; 261: 595-606.

27. Verna A, Barets A, Salat C. Distribution of sympathetic nerve endings within the rabbit carotid body: a histochemical and ultrastructural study. J Neurocytol 1984; 13: 849-865.

28. Wang ZZ, Bredt DS, Fidone SJ, Stensaas LJ. Neurons synthesizing nitric oxide the mammalian carotid body. $J$ Comp Neurol 1993; 336: 419-432.

29. Verna A. Ultrastructure of the carotid body in the mammals. Int Rev Cytol 1979; 60: 271-330.

30. Heym C, Kummer W. 1989. Immunohistochemical distribution and colocalization of regulatory peptides in the carotid body. J Electron Microsc Tech 12:31-42.

31. Fujita T, Kobayashi S, Kanno T. The Paraneuron. Springer, Berlin, 1988.

32. Hellström S. Morphometric studies of dense-cored vesicles in type I cells of rat carotid body. J Neurocytol 1975; 4: 77-86.

33. Kameda Y. Ultrastructural Immunogold localization of vimentin and S-100 protein in guinea pig pars tuberalis. J Histochem Cytochem 1996; 44: 511-518.

34. Kondo H., Iwanaga T, Nakajima T. Immunocytochemical study on the localization of neuron-specific enolase and S-100 protein in the carotid body of rats. Cell Tissue Res 1982; 227: 291-295.

35. Kondo H. Are there gap junctions between chief (glomus, type I) cells in the carotid body chemoreceptor? A review. Microsc Res Tech 2002;59:227-233.

36. Kondo H, Iwasa H. Re-examination of the carotid body ultrastructure with special attention to intercellular membrane appositions. Adv Exp Med Biol 1996; 410: 45-50.

37. Eyzaguirre C. Carotid body gap junctions: secretion of transmitters and possible electric coupling between glomus cells and nerve terminals. Adv Exp Med Biol 2000; 475: 349-357.

38. Eyzaguirre C, Abudara V. Reflection on the carotid nerve sensory discharge and coupling between glomus cells. $A d v$ Exp Med Biol 1996; 10: 159-167.

39. Morgan M, Pack RJ, Howe A. Nerve endings in rat carotid body. Cell Tissue Res 1975;157: 255-272.

40. Kondo H. Innervation of the carotid body of the adult rat. A serial ultrathin section analysis. Cell Tissue Res 1976;173: 1-15.

41. Kondo H. Innervation of the chief cells of the carotid body: an ultrastructural review. Arch Histol Jpn 1977; Suppl 40: 221-230.

42. Kondo H. Innervation of SIF cells in the superior cervical and nodose ganglia: an ultrastuctural study with serial sections. Biol Cell 1977; 30: 253-264.

43. Iturriaga R, Alcayaga J. Neurotransmission in the carotid body: transmitters and modulators between glomus cells and petrosal ganglion nerve terminals. Brain Res Rev 2004; 47: 46-53.

44. Eyzaguirre C, Fitzgerald RS, Lahiri S, Zapata P. Arterial chemoreceptors. In: Shepherd JT, Abboud FM, editors. Handbook of Physiology, Vol. 3. Williams \&Wilkins, Baltimore, 1983; 557-621.

45. De Castro F, Rubio M. The anatomy and innervation of the blood vessels of the carotid body and the role of chemoreceptove reactions in the autoregulation of the blood flow. In: Torrance RW, editor. Arterial Chemoreceptors. Blackwell, Oxford, 1968; 267-277.

46. McDonald DM, Lurue DT. The ultrastructure and connections of blood vessels supplying the rat carotid body and carotid sinus. J Neurocytol 1983; 12: 117-153.

47. McDonald DM, Haskell A. Morphology of connections between arteriols and capillaries in the rat carotid body analyzed by reconstructing serial sections. In: Pollot DJ, editor. The Peripheral Arterial Chemoreceptors. Croom Helm, London, 1984; 195-206.

48. Hollinshead WH. Effects of anoxia upon carotid body morphology. Anat Rec 1945; 92: 255-261.

49. Hoffman H, Birrel JHW. The carotid body in normal and anoxic states: an electron microscopic study. Acta Anat (Basel) 1958; 32: 297-311. 
50. Lahiri S, Rozanov C, Cherniack NS. Altered structure and function of the carotid body at high altitude and associated chemoreflexes. High Altitude Med Biol 2000; 1: 63-74.

51. Kusakabe T, Matsuda H, Hayashida Y. Hypoxic adaptation of the rat carotid body. Histol Histopathol 2005; 20: 987-997.

52. Pequignot J-M, Hellstrom S, Johansson C. Intact and sympathectomized carotid bodies of long-term hypoxic rats: a morphometric ultrastructural study. J Neurocytol 1984; 13: 481-493.

53. McGregor KH, Gil J, Lahiri S. A morphometric study of the carotid body in chronically hypoxic rats. J Appl Physiol 1984;57: 1430-1438.

54. Wang Z-Y, Biscard GE. Chronic hypoxia-induced morphological and neurochemical changes in the carotid body. Misrosc Res Tech 2002; 59: 168-177.

55. Kusakabe T, Powell FL, Ellisman MH. Ultrastructure of the glomus cells in the carotid body of chronically hypoxic rats: with a special reference to the similarity of the amphibian glomus cells. Anat Rec 1993; 237: 220-227.

56. Eyzaguirre C, AbudaraV. Carotid body glomus cells: chemical secretion and transmission (modulation?) across cell-nerve ending junctions. Respir Physiol 1999; 115: 135-149.

57. Laidler P, Kay JM. A quantitative morphological study of the carotid bodies of rats living at a stimulated altitude of 4300 metres. J Pathol 1975: 117: 183-191.

58. Chen J, Dinger B, Stensaas L, Fidone S. Involvement of vascular endothelial growth factor (VEGF) in carotid body vascular remodeling induced by chronic hypoxia. FASEB J 2001; A153.

59. Arias-Stell J, Valcarcel J. Chief cell hyperplasia in the human carotid body at high altitudes; physiologic and pathologic significance. Hum Pathol 1976; 7: 361-373.

60. Heath D, Smith P. The Pathology of the Carotid Body and Sinus, Vol. 17. Edward Arnold Publishers Ltd, Baltimore, 1985.

61. Fitzgerald RS, Eyzaguirre C, Zapata P. Fifty years of progress in carotid body physiology. In: Gonzalez C, Nurse CA, Peers C, editors. Arterial Chemoreceptors, Advances in Experimental Medicine and Biology, Vol. 648, Springer, Dordrecht, 2009; 19-28.

62. Zhang M, Zhong H, Vollmer C, Nurse CA. Co-release of ATP and ACh mediates hypoxic signalling at rat carotid body chemoreceptors. J Physiol 2000; 525: 143-158.

63. Zapata P. Is ATP a suitable co-transmitter in carotid body arterial chemoreceptors? Respir Physiol Neurobiol 2007; 157: 106-115.

64. Bisgard GE. Carotid body mechanisms in acclimatization to hypoxia. Respir Physiol 2000;121: 237-246.

65. Koerner P, Hesslinger C, Schaefermeyer A, Prinz C, Gratzl M. Evidence for histamine as a transmitter in rat carotid body sensor cell. J Neurochem 2004; 91: 493-500.

66. Lazarov N, Rozloznik M, Reindl S, Rey-Ares V, Dutschmann M, Gratzl M. Expression of histamine receptors and effect of histamine in the rat carotid body chemoafferent pathway. Eur J Neurosci 2006; 24: 3431-3444.

67. Yamamoto Y, König P, Henrich M, Dedio J, Kummer W. Hypoxia induces production of nitric oxide and reactive oxygen species in glomus cells of rat carotid body. Cell Tissue Res 2006; 325: 3-11.

68. Prabhakar NR. NO and CO as second messengers in oxygen sensing in the carotid body. Respir Physiol 1999;115: 161-168.

69. Kusakabe T, Hirakawa H, Oikawa S, Matsuda H, Kawakami T, Takenaka T, Hayashida Y. Peptidergic innervation in the rat carotid body after 2,4 , and 8 weeks of hypocapnic hypoxic exposure. Histol Histopathol 2003; 18: 409-418.

70. Prabhakar NR, Peng Y-J. Peripheral chemoreceptors in health and disease. J Appl Physiol 2004; 96: 359-366.

71. Jansen AH, Ioffe S, Russell BJ, Chernick V. Effect of carotid chemoreceptor denervation on breathing in utero and after birth. J Appl Physiol 1981; 51: 630-633.

72. Gauda EB, Cristofalo E, Nunez J. Peripheral arterial chemoreceptors and sudden infant death syndrome. Resp Physiol Neurobiol 2007; 157: 162-170.

73. Naeye RL, Fisher R, Ryser M, Whalen P. Carotid body in the sudden infant death syndrome. Science 1976; 191: 567-569.

74. Perrin DG, Cutz E, Becker LE, Bryan AC, Madapallimatum A, Sole MJ. Sudden infant death syndrome: increased carotid-body dopamine and noradrenaline content. Lancet 1984; 2: 535-537.

75. Holgert H, Hökfelt T, Hertzberg T, Lagercrantz H. Functional and developmental studies of the peripheral arterial chemoreceptors in rat: effects of nicotine and possible relation to sudden infant death syndrome. Proc Natl Acad Sci USA 1995; 92: 7575-7579.

76. Cutz E, Ma TK, Perrin DG, Moore AM, Becker LE. Peripheral chemoreceptors in congenital central hypoventilation syndrome. Am J Respir Crit Care Med 1997; 155: 358-363. 
77. Habeck JO. Peripheral arterial chemoreceptors and hypertension. J Auton Nerv Syst 1991; 34: 1-7.

78. Fletcher EC, Lesske J, Behm R, Miller CC, Stauss H, Unger T. Carotid chemoreceptors, systemic blood pressure, and chronic episodic hypoxia mimicking sleep apnea. $J$ Appl Physiol 1992; 72: 1978-1984.

79. Calverley PM. Blood pressure, breathing, and the carotid body. Lancet 1999; 354: 969-970.

80. Espejo EF, Montoro RJ, Armengol JA, López-Barneo J. Cellular and functional recovery of Parkinsonian rats after intrastriatal transplantation of carotid body cell aggregates. Neuron 1998;20: 197-206.

81. Arjona V, Mínguez-Castellanos A, Montoro RJ, Ortega A, Escamilla F, Toledo-Aral JJ, et al. Autotransplantation of human carotid body cell aggregates for treatment of Parkinson's disease. Neurosurgery 2003; 53: 321-328.

82. Toledo-Aral JJ, Méndez-Ferrer S, Pardal R, LópezBarneo J. Dopaminergic cells of the carotid body: physiological significance and possible therapeutic applications in Parkinson's disease. Brain Res Bull 2002;57: 847-853.

83. Mínguez-Castellanos A, Escamilla-Sevilla F, Hotton GR, Toledo-Aral JJ, Ortega-Moreno A, et al. Carotid body autotransplantation in Parkinson disease: a clinical and positron emission tomography study. J Neurol Neurosurg Psychiatry 2007; 78: 825-831.

84. Yu G, Fournier C, David Hess DC, Borlongan CV. Transplantation of carotid body cells in the treatment of neurological disorders. Neurosci Biobehav Rev 2005; 28 : 803-810. 